\title{
LAYANAN BIMBINGAN KELOMPOK UNTUK MENINGKATKA KETERAMPILAN BELAJAR SISWA
}

\author{
Anis Nuril Laili Sulistyowati \\ SMA Negeri 1 Kudus, Jawa Tengah, Indonesia \\ nuril_lely@yahoo.co.id
}

\begin{abstract}
Abstrak
Artikel ini ditulis untuk memberikan gambaran tentang layanan bimbingan kelompok dalam meningkatkan keterampilan belajar siswa kelas X MIA 8 SMA Negeri 1 Kudus. Untuk maksud tersebut penulis menggunakan metode observasi yang dilaksanakan dalam dua siklus. Analisa data dalam penelitian ini menggunakan analisis deskriptif prosentase dengan cara membandingkan skor hasil penghitungan dari kondisi awal hingga siklus kedua sehingga peningkatan keterampilan belajar melalui layanan bimbingan kelompok pada siswa kelas X MIA 8 SMA Negeri 1 Kudus dapat diukur dan diketahui dengan valid dan tepat. Layanan bimbingan kelompok ini menunjukkan peningkatan keterampilan belajar siswa. Berdasarkan hasil, dari 11 subjek penelitian menunjukkan peningkatan keterampilan belajar siswa rata-rata 12. Dengan peningkatan keterampilan belajar ini diharapkan dapat membantu siswa dalam mencapai prestasi yang optimal.
\end{abstract}

Kata kunci: keterampilan, belajar, bimbingan, kelompok

\begin{abstract}
GROUP COUNSELING SERVICE TO IMPROVE STUDENTS' LEARNING SKILLS. This article was written to provide an overview of group counseling services in improving the student's learning skills of
\end{abstract}


class X MIA 8 SMA Negeri 1 Kudus. For that purpose, the researcher used the method of observation which was done in two cycles. The data analysis in this research use the descriptive analysis percentage by comparing the extrapolation result score of the first condition to the second cycle with the result that the students of Class MIA 8 SMA Negeri 1 Kudus skills improvement can be measured and known accurately and valid. This group counseling service showed an increase in students' learning skills. Based on the results, the study of 11 subjects showed an increase in students' learning skills of the average 12. With the improvement of learning skills is expected to assist students in achieving optimal performance.

Keywords: skills, learning, group counseling service

\section{A. Pendahuluan}

Belajar merupakan salah satu faktor yang mempengaruhi dan berperan penting dalam pembentukan pribadi dan perilaku individu. Sebuah proses belajar mempunyai unsur-unsur yang penting di dalamnya yang berpengaruh terhadap hasil belajar itu sendiri. Dalam suatu proses belajar pasti ada hambatan-hambatan dan masalah yang dihadapi oleh siswa. Masalah-masalah tersebut dapat diminimalisir dengan berbagai cara atau metode. Salah satunya adalah dengan cara menguasai keterampilan-keterampilan belajar.

Keterampilan belajar dimaksudkan untuk meningkatkan kemampuan individu dalam aspek terpenting dalam belajar; pertama untuk lebih memahami konsep belajar untuk belajar, dan yang kedua menekankan implikasi praktis dari konsep tersebut pada aplikasi nyata dalam aktivitas sehari-hari seperti proses belajar mengajar, training, konseling, pengembangan program dan melaksanakan program di dalam lingkup akademik (Djamal, 2006: 10).

Berdasarkan observasi di lapangan diperoleh beberapa siswa kelas X MIA 8 memiliki keterampilan belajar yang kurang baik seperti manajemen waktu yang belum baik, kurangnya perhatian terhadap mata pelajaran, kurang aktif bertanya saat pelajaran, dan penggunaan sumber belajar yang kurang optimal. Menurut Prayitno (2004: 1) layanan bimbingan kelompok merupakan proses pemberian informasi dan bantuan pada sekelompok orang dengan memanfaatkan dinamika kelompok guna mencapai suatu tujuan tertentu. Layanan yang diberikan dalam suasana kelompok selain itu juga bisa dijadikan media 
penyampaian informasi sekaligus juga bisa membantu siswa menyusun rencana dalam membuat keputusan yang tepat sehingga diharapkan akan berdampak positif bagi siswa yang nantinya akan meningkatkan keterampilan belajar. Selain itu apabila dinamika kelompok dapat terwujud dengan baik maka anggota kelompok saling membantu, menerima dan berempati dengan tulus. Bimbingan kelompok merupakan lingkungan yang kondusif yang memberikan kesempatan bagi anggotanya untuk menambah penerimaan diri dan orang lain, memberikan ide, perasaan, dukungan, bantuan alternatif pemecahan masalah dan mengambil keputusan yang tepat, dan bertanggung jawab atas pilihan yang ditentukannya sendiri. Suasana ini dapat menumbuhkan perasaan berarti bagi anggota yang selanjutnya juga dapat meningkatkan keterampilan belajar siswa.

Berdasarkan uraian di atas, rumusan masalah dalam penelitian ini adalah bagaimana layanan bimbingan kelompok dapat meningkatkan keterampilan belajar siswa kelas X MIA 8 SMA N 1 Kudus Tahun Pelajaran 2014/ 2015? Sedangkan tujuan penelitian ini adalah (1) mendeskripsikan peningkatan keterampilan belajar siswa setelah diberi layanan bimbingan kelompok untuk meningkatkan keterampilan belajar siswa, (2) menemukan keefektifan layanan bimbingan kelompok untuk meningkatkan keterampilan belajar.

\section{B. Pembahasan}

\section{Keterampilan Belajar}

Kata keterampilan sama artinya dengan kata kecekatan. Terampil atau cekatan adalah kepandaian melakukan sesuatu dengan cepat dan benar. Seseorang yang dapat melakukan sesuatu dengan cepat tetapi salah tidak dapat dikatakan terampil. Demikian pula apabila seseorang dapat melakukan sesuatu dengan benar tetapi lambat, juga tidak sapat dikatakan terampil (Soemarjadi, 1991:2). Sedangkan Surya (1992: 28) mengungkapkan bahwa keterampilan merupakan kegiatan-kegiatan yang bersifat neuromuscular, artinya menuntut kesadaaran yang tinggi. Dibandingkan dengan kebiasaan, keterampilan merupakan kegiatan yang lebih membutuhkan perhatian serta kemampuan intelektualitas, selalu berubah dan sangat disadari oleh individu.

Dari definisi di atas dapat disimpulkan bahwa keterampilan 
belajar merupakan suatu teknik yang digunakan untuk memperoleh, mempertahankan, serta mengungkapkan pengetahuan dan merupakan cara untuk menyelesaikan persoalan. Dalam memperoleh keterampilan belajar, siswa akan menyadari bagaimana cara belajar yang terbaik sehingga menjadi lebih bertanggungjawab terhadap kegiatan belajarnya.

\section{Layanan Bimbingan Kelompok}

Menurut Gazda sebagaimana dikutip oleh Prayitno dan Amti (1999: 309) bimbingan kelompok di sekolah merupakan kegiatan informasi kepada sekelompok siswa untuk membantu siswa menyusun rencana dan keputusan yang tepat. Pengertian di atas menekankan pada kegiatan pemberian informasi dalam suasana kelompok dan adanya penyusunan rencana untuk mengambil keputusan. Menurut Prayitno (1995: 61) bahwa "Bimbingan kelompok adalah memanfaatkan dinamika untuk mencapai tujuan-tujuan bimbingan dan konseling, bimbingan kelompok lebih menekankan suatu upaya bimbingan kepada individu melalui kelompok”. Sedangkan Winkel (1991: 71) mengatakan bahwa "bimbingan adalah proses membantu seseorang dalam memahami dirinya sendiri dan lingkungannya”. Bimbingan kelompok menekankan bahwa kegiatan bimbingan kelompok lebih pada proses pemahaman diri dan lingkungannya yang dilakukan oleh satu orang atau lebih yang disebut kelompok. Apabila konseling perorangan menunjukkan layanan kepada individu atau klien orang per orang, maka bimbingan kelompok mengarahkan layanan kepada sekelompok individu.

Bimbingan kelompok bersifat memberikan kemudahan dalam pertumbuhan dan perkembangan individu, dalam arti bahwa bimbingan kelompok itu memberi dorongan dan motivasi kepada individu untuk mengubah diri dengan memanfaatkan kemampuan yang dimiliki secara optimal, sehingga mempunyai kebiasaan belajar efektif. Dengan demikian bimbingan kelompok adalah proses pemberian informasi dan bantuan yang diberikan oleh seorang yang ahli (konselor) pada sekelompok orang dengan memanfaatkan dinamika kelompok guna mencapai suatu tujuan tertentu, tujuan dalam penelitian ini adalah meningkatkan keterampilan belajar siswa. 
Tahap-tahap perkembangan kelompok dalam bimbingan melalui pendekatan kelompok sangat penting yang pada dasarnya tahapan perkembangan kegiatan bimbingan kelompok sama dengan tahapan yang terdapat dalam konseling kelompok. Prayitno (1995: 40-60) menjelaskan tahap-tahap bimbingan kelompok ada empat tahap, yaitu: tahap pembentukan, tahap peralihan, tahap kegiatan, dan tahap pengakhiran. Dalam penelitian tindakan kelas, perlu difikuskan pada tiga tahapan mulai dari memotret kondisi awal peserta didik, perjalanan per-siklus dan penutup. Berikut penulis dapatkan beberapa gambaran masing-masingnya:

\section{a. Kondisi Awal}

Pada observasi awal, peneliti menemukan beberapa siswa yang memiliki keterampilan belajar rendah. Hal tersebut meliputi siswa-siswi memiliki kecenderungan kurang dapat mengatur waktu belajar, kurang perhatian terhadap mata pelajaran dan kurangnya konsentrasi pada saat pelajaran, dan kurangnya persiapan dalam menghadapi ujian. Kesemua siswa tersebut berinisial FYA, FYU, IN, INO, IST, MRZZ, MAA, MHH, MSS, RHU, YAA.

\section{b. Siklus I}

Pada siklus I peneliti melakukan layanan bimbingan kelompok pada kesebelas siswa yang menjadi subjek penelitian. Layanan bimbingan kelompok dilakukan sebanyak 2 kali dengan peneliti sebagai pemimpin kelompok. Pada tahap pelaksanaan siklus I ini terdiri dari empat kegiatan utama yaitu muliai dari perencanaan (planning), tindakan (action), pengamatan (observation), dan refleksi (reflection). Selain itu, dalam penelitian ini peneliti juga dibantu oleh seorang guru bimbingan dan konseling yang bertindak sebagai kolaborator. Untuk lebih jelasnya, setiap tahapan akan dijelaskan sebagai berikut:

\section{1) Perencanaan (Planning)}

Perencanaan awal yang dilakukan oleh peneliti yaitu menyusun satuan layanan (SATLAN), menyusun program perencanaan layanan bimbingan kelompok, menyiapkan lembar observasi untuk peneliti dan anggota bimbingan kelompok. Peneliti juga melakukan pengamatan terhadap kegiatan sehari-hari siswa dan bekerja sama dengan guru mata pelajran untuk mengetahui keterampilan belajar siswa. 


\section{2) Pelaksanaan Tindakan (Action)}

Tahap yang kedua adalah melaksanakan kegiatan penelitian seperti yang telah direncanakan. Pelaksanaan kegiatan layanan bimbingan kelompok dilakukan di ruang BK SMA 1 Kudus. Siklus I dilaksanakan pada tanggal 28 Oktober 2014 dan 4 November 2014.

\section{3) Pengamatan (Observation)}

Pengamatan atau observasi terhadap aktivitas peneliti oleh kolaborator dalam memberikan layanan bimbingan kelompok yaitu pada setiap tahapannya yang bertugas sebagai pemimpin kelompok, dan aktivitas siswa sebagai anggota kelompok dalam mengikuti layanan bimbingan kelompok.

Adapun hasil observasi kolaborator terhadap aktivitas peneliti selama memberikan layanan bimbingan kelompok adalah sebagai berikut:

Tabel 4.1

Hasil Observasi Kolaborator terhadap Aktivitas Peneliti pada Siklus I

\begin{tabular}{clcc}
\hline \multirow{2}{*}{ No } & \multirow{2}{*}{ Tahap } & $\mathbf{2}$ & Pertemuan \\
\cline { 3 - 4 } & & 12 & $\mathbf{2}$ \\
\hline 1 & Pembukaan & 8 & 15 \\
\hline 2 & Peralihan & 12 & 10 \\
\hline 3 & Kegiatan & 10 & 16 \\
\hline 4 & Pengakhiran & $\mathbf{4 2}$ & 11 \\
\hline Jumlah & Kurang & Cukup \\
\hline Kategori & &
\end{tabular}

Berdasarkan tabel 4.1 di atas, pelaksanaan bimbingan kelompok sebagai upaya meningkatkan keterampilan belajar siswa pada siklus I dalam kategori cukup. Pada pertemuan pertama kegiatan peneliti mendapatkan hasil 42 dengan kategori kurang. Hal ini disebabkan peneliti lebih mendominasi peran sebagai pemimpin kelompok, kurang memperhatikan keikutsertaan siswa, dan kurang dalam mengendalikan diri. Selanjutnya pada pertemuan kedua, aktivitas peneliti mendapatkan hasil 52 ada peningkatan 10. Pada pertemuan kedua ini, peneliti lebih bisa menghidupkan suasana dalam kelompok melalui dinamika kelompok sehingga siswa merasa lebih aktif dalam layanan bimbingan kelompok. 
Tabel 4.2

Hasil Observasi Peneliti terhadap Aktivitas Siswa dalam Mengikuti Layanan Bimbingan Kelompok Siklus I

\begin{tabular}{clcc}
\hline \multirow{2}{*}{ No } & \multirow{2}{*}{ Subjek } & \multicolumn{2}{c}{ Pertemuan } \\
\cline { 3 - 4 } & & 1 & 2 \\
\hline 1 & FYA & 20 & 29 \\
\hline 2 & FYU & 21 & 30 \\
\hline 3 & IN & 21 & 29 \\
\hline 4 & INO & 22 & 28 \\
\hline 5 & IST & 20 & 30 \\
\hline 6 & MRZZ & 21 & 29 \\
\hline 7 & MAA & 21 & 30 \\
\hline 8 & MHH & 22 & 29 \\
\hline 9 & MSS & 23 & 31 \\
\hline 10 & RHU & 20 & 30 \\
\hline 11 & YAA & 20 & 30 \\
\hline Jumlah & & 231 & 325 \\
\hline Rata-rata: Jumlah Subjek $(11)$ & 21 & 29 \\
\hline Kategori & Kurang & Cukup \\
\hline
\end{tabular}

Berdasarkan tabel 4.2 di atas, dapat diketahui efektifitas layanan bimbingan kelompok sebagai upaya meningkatkan keterampilan belajar siswa. Pada siklus I pertemuan pertama, aktivitas siswa dalam mengikuti layanan bimbingan kelompok baru mencapai skor 21. Hal ini menunjukkan bahwa siswa belum begitu antusias dalam mengikuti layanan bimbingan kelompok.

Pada pertemuan kedua, aktivitas siswa dalam mengikuti layanan bimbingan kelompok diperoleh hasil sebesar 29, ada peningkatan sebesar 7. Peningkatan ini terjadi karena siswa sudah lebih nyaman dalam layanan bimbingan kelompok.

Dengan demikian, tindakan selanjutnya yang akan dilakukan oleh peneliti yaitu melakukan observasi/pengamatan terhadap kemampuan keterampilan belajar siswa anggota layanan bimbingan kelompok. 
Anis Nuril Laili Sulistyowati

Tabel 4.3

Hasil Observasi Peneliti terhadap Keterampilan Belajar Siswa pada Siklus I

\begin{tabular}{clcc}
\hline \multirow{2}{*}{ No } & & Subjek & \multicolumn{2}{c}{ Pertemuan } \\
\cline { 3 - 4 } 1 & FYA & 20 & 2 \\
\hline 2 & FYU & 20 & 26 \\
\hline 3 & IN & 20 & 26 \\
\hline 4 & INO & 20 & 25 \\
\hline 5 & IST & 21 & 26 \\
\hline 6 & MRZZ & 21 & 28 \\
\hline 7 & MAA & 21 & 28 \\
\hline 8 & MHH & 22 & 27 \\
\hline 9 & MSS & 21 & 26 \\
\hline 10 & RHU & 22 & 28 \\
\hline 11 & YAA & 22 & 27 \\
\hline Jumlah & 230 & 292 \\
\hline Rata-rata: Jumlah Subjek $(11)$ & 21 & 26 \\
\hline Kategori & Kurang & Cukup \\
\hline
\end{tabular}

Berdasarkan tabel 4.3 di atas, dapat diketahui keterampilan belajar siswa masih dikatakan rendah. Peneliti melakukan observasi pada kegiatan sehari-hari siswa dan juga bekerja sama dengan guru mata pelajaran untuk mengetahui keterampilan belajar siswa. Setelah dilakukan layanan bimbingan kelompok pada siklus I pertemuan pertama memperoleh skor 21 . Selanjutnya setelah dilakukan layanan bimbingan kelompok pada pertemuan kedua, keterampilan belajar meningkat sebesar 26 .

\section{4) Refleksi (Reflection)}

Berdasarkan hasil observasi pada siklus I diperoleh data bahwa pelaksanaan layanan bimbingan kelompok sebagai upaya meningkatkan keterampilan belajar siswa sudah dapat dikatakan meningkat, tapi belum sepenuhnya memuaskan. Pada aktivitas peneliti selama memberikan layanan bimbingan kelompok pada 
siklus I rata-rata memperoleh skor 47, akan tetapi masih ada beberapa kelemahan yang harus diperbaiki oleh peneliti. Adapun kelemahan peneliti dan siswa setelah dianalisis dan refleksi dari tindakan pada siklus I dijabarkan pada tabel sebagai berikut:

Tabel 4.4

Kelemahan Peneliti dan Siswa pada Siklus I

\begin{tabular}{|c|c|c|c|}
\hline $\mathrm{NO}$ & Kelemahan Peneliti & Kelemahan Siswa & $\begin{array}{l}\text { Rencana Tindakan } \\
\text { Perbaikan }\end{array}$ \\
\hline 1 & $\begin{array}{l}\text { Peneliti belum } \\
\text { memberikan dinamika } \\
\text { kelompok kepada } \\
\text { anggota kelompok } \\
\text { dan peneliti masih } \\
\text { mendominasi } \\
\text { kelompok }\end{array}$ & $\begin{array}{l}\text { Siswa belum aktif } \\
\text { dalam layanan } \\
\text { bimbingan } \\
\text { kelompok. }\end{array}$ & $\begin{array}{l}\text { Peneliti lebih } \\
\text { menekan kan } \\
\text { dinamika } \\
\text { kelompok dan } \\
\text { memberikan } \\
\text { kesempatan kepada } \\
\text { anggota kelompok } \\
\text { untuk berpendapat }\end{array}$ \\
\hline 2 & $\begin{array}{l}\text { Peneliti tidak optimal } \\
\text { dalam tahapan layanan } \\
\text { bimbingan kelompok }\end{array}$ & $\begin{array}{l}\text { Anggota } \\
\text { kelompok masih } \\
\text { belum berani } \\
\text { berpendapat }\end{array}$ & $\begin{array}{l}\text { Memperhatikan } \\
\text { tahapan-tahapan } \\
\text { dalam bimbingan } \\
\text { kelompok dan } \\
\text { memotivasi } \\
\text { anggota kelompok } \\
\text { untuk berani } \\
\text { berpendapat }\end{array}$ \\
\hline
\end{tabular}

Berdasarkan tabel di atas menunjukan hasil analisis dan refleksi tindakan pada siklus I masih terdapat beberapa kelemahan dari peneliti saat memberikan layanan dan aktivitas siswa pada layanan bimbingan kelompok, maka perlu dilakukan tindakan perbaikan melalui siklus II.

\section{c. Siklus II}

1) Perencanaan (Planning)

Berdasarkan hasil refleksi pada siklus I, proses layanan bimbingan kelompok masih perlu dilakukan lagi pada siklus II untuk meningkatkan keterampilan belajar siswa. Pada siklus II, peneliti berencana melakukan perbaikan pada kelemahan-kelemahan yang 
ditemukan pada siklus I baik dari kelemahan peneliti maupun kelemahan dari siswa.

\section{2) Pelaksanaan (Action)}

Penelitian tindakan bimbingan dan konseling (PTBK) pada siklus II dilaksanakan sebanyak 2 kali layanan seperti yang dilakukan pada siklus I. Layanan bimbingan kelompok dilaksanakan pada tanggal 11 November 2014 dan 18 November 2014. Selama layanan berlangsung peneliti melakukan pengamatan terhadap aktivitas siswa dalam bimbingan kelompok. Pada saat yang sama kolaborator melaksanakan observasi aktivitas peneliti selama memberikan layanan bimbingan kelompok.

\section{3) Pengamatan (Observation)}

Hasil pengamatan kolaborator terhadap aktivitas peneliti dijelaskan pada tabel berikut.

Tabel 4.5

Hasil Observasi Kolaborator terhadap Aktivitas Peneliti Pada Siklus II

\begin{tabular}{llcc}
\hline \multirow{2}{*}{ No } & \multirow{2}{*}{ Tahap } & \multicolumn{2}{c}{ Pertemuan } \\
\cline { 3 - 4 } & & $\mathbf{1}$ & $\mathbf{2}$ \\
\hline 1 & Awal & 19 & 23 \\
\hline 2 & Peralihan & 14 & 15 \\
\hline 3 & Kegiatan & 18 & 22 \\
\hline 4 & Pengakhiran & 13 & 16 \\
\hline Jumlah & $\mathbf{6 4}$ & $\mathbf{7 6}$ \\
\hline Kategori & Baik & Baik \\
\hline
\end{tabular}

Berdasarkan tabel 4.5 di atas, kemampuan peneliti di dalam melaksanakan layanan bimbingan kelompok pada pertemuan pertama siklus II ini bisa dikategorikan sudah baik dan menunjukkan adanya peningkatan sebesar 64 dari siklus sebelumnya. Selanjutnya pada pertemuan kedua memperoleh skor 76 ada peningkatan 12 poin dari pertemuan sebelumnya. 
Tabel 4.6

Hasil Observasi Peneliti terhadap Aktivitas Siswa dalam Mengikuti Layanan Bimbingan Kelompok pada Siklus II

\begin{tabular}{clcc}
\hline \multirow{2}{*}{ No } & & Subjek & \multicolumn{2}{c}{ Pertemuan } \\
\cline { 3 - 4 } & & $\mathbf{1}$ & $\mathbf{2}$ \\
\hline 1 & FYA & 32 & 37 \\
\hline 2 & FYU & 35 & 38 \\
\hline 3 & IN & 35 & 38 \\
\hline 4 & INO & 36 & 39 \\
\hline 5 & IST & 37 & 40 \\
\hline 6 & MRZZ & 35 & 38 \\
\hline 7 & MAA & 35 & 40 \\
\hline 8 & MHH & 35 & 39 \\
\hline 9 & MSS & 37 & 39 \\
\hline 10 & RHU & 38 & 39 \\
\hline 11 & YAA & 37 & 39 \\
\hline Jumlah & & $\mathbf{3 9 2}$ & $\mathbf{4 2 6}$ \\
\hline Rata-rata: Jumlah Subjek (1) & $\mathbf{3 5}$ & $\mathbf{3 8}$ \\
\hline Kategori & Baik & Baik \\
\hline
\end{tabular}

Berdasarkan tabel 4.6 di atas, maka dapat diketahui bahwa layanan bimbingan kelompok menunjukkan minat dan antusias yang senantiasa meningkat dari tiap pertemuan selama siklus II. Dengan demikian, pada siklus II pertemuan pertama memperoleh skor 35 dengan kategori baik dan menunjukkan adanya peningkatan pada pertemuan kedua dengan skor sebesar 38 dengan kategori baik.

Selanjutnya peneliti melakukan pengamatan terhadap 11 siswa yang menjadi subjek penelitian dan melakukan kerja sama dengan guru mata pelajaran untuk mengetahui keterampilan belajar. Adapun hasil observasi tersebut adalah sebagai berikut:

Tabel 4.7

Hasil Observasi Peneliti terhadap Keterampilan Belajar Siswa pada Siklus II

\begin{tabular}{ccccc}
\hline \multirow{2}{*}{ No } & \multirow{2}{*}{ Subjek } & \multicolumn{2}{c}{ Pertemuan } \\
\cline { 3 - 5 } & & & $\mathbf{1}$ & $\mathbf{2}$ \\
\hline 1 & FYA & & 30 & 37 \\
\hline
\end{tabular}




\begin{tabular}{clcc}
\hline 2 & FYU & 31 & 38 \\
\hline 3 & IN & 32 & 39 \\
\hline 4 & INO & 33 & 40 \\
\hline 5 & IST & 33 & 38 \\
\hline 6 & MRZZ & 32 & 37 \\
\hline 7 & MAA & 33 & 40 \\
\hline 8 & MHH & 32 & 40 \\
\hline 9 & MSS & 32 & 37 \\
\hline 10 & RHU & 31 & 40 \\
\hline 11 & YAA & 33 & 39 \\
\hline Jumlah & $\mathbf{3 5 2}$ & $\mathbf{4 2 5}$ \\
\hline Rata-rata: Jumlah Subjek (11) & $\mathbf{3 2}$ & $\mathbf{3 8}$ \\
\hline Kategori & Cukup & Baik \\
\hline
\end{tabular}

Berdasarkan tabel 4.7 di atas, dapat diketahui keterampilan belajar siswa pada siklus II sudah bisa dikatakan baik. Pada siklus II setelah pertemuan pertama bimbingan kelompok, keterampilan belajar siswa mencapai skor 32, hal tersebut dapat dikategorikan cukup. Siswa sudah dapat membagi waktu dengan cukup baik dan dapat membuat jadwal harian. Selanjutnya setelah pertemuan kedua, keterampilan belajar siswa mengalami peningkatan sebesar 38 kategori baik. Siswa mulai berani bertanya pada saat pelajaran, memiliki kemauan belajar yang kuat, dan memperhatikan pelajaran.

\section{4) Refleksi (Reflection)}

Berdasarkan hasil observasi pada siklus II ini terjadi peningkatan dari siklus sebelumnya. Berikut adalah refleksi pada siklus II hasil observasi aktivitas peneliti, aktivitas mahasiswa selama mengikuti layanan bimbingan kelompok, serta observasi tentang keterampilan belajar siswa diuraikan sebagai berikut:

\section{5) Aktivitas Peneliti}

Aktivitas peneliti dalam memberikan layanan bimbingan kelompok secara signifikan mengalami peningkatan hasil sebesar 23. Secara keseluruhan siklus II peneliti melaksanakan beberapa inovasi di dalam layanan dan memperoleh rata-rata sebesar 70 dengan kategori baik. Hal ini menunjukkan adanya peningkatan dibandingkan dengan siklus I hanya sebesar 47. 
Tabel 4.8

Perbandingan Hasil Observasi Kolaborator terhadap Aktivitas Peneliti Pada Siklus I dan Siklus II

\begin{tabular}{|c|c|c|c|c|c|c|}
\hline \multirow{3}{*}{ No } & \multirow{3}{*}{ Tahap-tahap } & & \multicolumn{4}{|c|}{ Jumlah Skor } \\
\hline & & & \multicolumn{2}{|c|}{ Siklus I } & \multicolumn{2}{|c|}{ Siklus II } \\
\hline & & & 1 & 2 & 1 & 2 \\
\hline & Awal & .1 & 12 & 15 & 19 & 23 \\
\hline & Peralihan & .2 & 8 & 10 & 14 & 15 \\
\hline & Kegiatan & .3 & 12 & 16 & 18 & 22 \\
\hline \multirow{2}{*}{\multicolumn{2}{|c|}{ Penutup }} & .4 & 10 & 11 & 13 & 16 \\
\hline & & Jumlah & 42 & 52 & 64 & 76 \\
\hline \multicolumn{3}{|c|}{ Rata-rata } & 47 & & 70 & \\
\hline \multicolumn{3}{|c|}{ Kategori } & Kurang & & Baik & \\
\hline \multicolumn{3}{|c|}{ Peningkatan } & 23 & & & \\
\hline
\end{tabular}

Berdasarkan tabel 4.8 di atas, maka dapat dilihat bahwa hasil observasi terhadap aktivitas peneliti mengalami peningkatan memimpin bimbingan kelompok mulai dari siklus I pertemuan pertama dan kedua hingga siklus II pertemuan pertama dan kedua. Peningkatan ini dilakukan untuk meningkatkan keaktifan siswa dalam mengikuti bimbingan kelompok.

\section{6) Aktivitas Siswa}

Aktivitas siswa pada siklus II ini mencapai hasil rata-rata sebesar 37 sedangkan pada siklus sebelumnya hanya memperoleh hasil rata-rata sebesar 25. Hal tersebut menunjukkan adanya peningkatan dari siklus sebelumnya. Hal ini ditunjukkan dengan antusiasme siswa selama mengikuti layanan bimbingan kelompok. Jika dibandingkan pada siklus I, pada siklus II ini siswa lebih terbuka, aktif dan sukarela dalam diskusi.

\section{Tabel 4.9}

Perbandingan Hasil Observasi Peneliti terhadap Aktivitas Siswa Selama Mengikuti Bimbingan Kelompok pada Siklus I dan II

\begin{tabular}{cccccc}
\hline NO & SUBJEK & \multicolumn{3}{c}{ JUMLAH SKOR } \\
\hline & & \multicolumn{2}{c}{ Siklus I } & \multicolumn{2}{c}{ Siklus II } \\
\hline & & 1 & 2 & 1 & 2 \\
\hline 1 & FYA & 20 & 29 & 32 & 37 \\
\hline
\end{tabular}


Anis Nuril Laili Sulistyowati

\begin{tabular}{|c|c|c|c|c|c|}
\hline 2 & FYU & 21 & 30 & 35 & 38 \\
\hline 3 & IN & 21 & 29 & 35 & 38 \\
\hline 4 & INO & 22 & 28 & 36 & 39 \\
\hline 5 & IST & 20 & 30 & 37 & 40 \\
\hline 6 & MRZZ & 21 & 29 & 35 & 38 \\
\hline 7 & MAA & 21 & 30 & 35 & 40 \\
\hline 8 & MHH & 22 & 29 & 35 & 39 \\
\hline 9 & MSS & 23 & 31 & 37 & 39 \\
\hline 10 & RHU & 20 & 30 & 38 & 39 \\
\hline \multirow[t]{5}{*}{11} & YAA & 20 & 30 & 37 & 39 \\
\hline & Jumlah & 231 & 325 & 392 & 426 \\
\hline & Rata-Rata & 25 & & 37 & \\
\hline & Kategori & Cukup & & Baik & \\
\hline & Peningkatan & 12 & & & \\
\hline
\end{tabular}

Berdasarkan pada tabel 4.9 di atas maka dapat dilihat bahwa aktivitas siswa selama mengikuti layanan bimbingan kelompok pada siklus II memperoleh hasil rata-rata sebesar 37 dan dikategorikan baik. Hal tersebut menunjukkan adanya peningkatan bila dibandingkan dengan siklus I yang memperoleh hasil rata-rata sebesar 25 dengan kategori cukup. Melihat perbandingan tersebut, maka pada siklus II memperoleh peningkatan rata-rata sebesar 12 .

Tabel 4.10

Perbandingan Hasil Observasi Keterampilan Belajar Siswa Siklus I dan II

\begin{tabular}{llllll}
\hline \multirow{2}{*}{ NO } & \multirow{2}{*}{ SUBJEK } & \multicolumn{3}{c}{ JUMLAH SKOR } \\
\cline { 3 - 6 } & & \multicolumn{2}{c}{ Siklus I } & \multicolumn{3}{c}{ Siklus II } \\
\hline & & 20 & 26 & 30 & 37 \\
\hline 1 & FYA & 20 & 26 & 31 & 38 \\
\hline 2 & FYU & 20 & 25 & 32 & 39 \\
\hline 3 & IN & 20 & 26 & 33 & 40 \\
\hline 4 & INO & 21 & 28 & 33 & 38 \\
\hline 5 & IST & 21 & 28 & 32 & 37 \\
\hline 6 & MRZZ & 21 & 27 & 33 & 40 \\
\hline 7 & MAA & 22 & 26 & 32 & 40 \\
\hline 8 & MHH & 21 & 28 & 32 & 37 \\
\hline 9 & MSS & 22 & 27 & 31 & 40 \\
\hline 10 & RHU & 22 & 25 & 33 & 39 \\
\hline 11 & YAA & & & & \\
\hline & & & 22 &
\end{tabular}


Layanan Bimbingan Kelompok...

\begin{tabular}{lllll}
\hline Jumlah & 230 & 292 & 352 & 425 \\
\hline Rata-Rata & 23 & & 35 & \\
\hline Kategori & Kurang & & Baik & \\
\hline Peningkatan & 12 & & \\
\hline
\end{tabular}

Berdasarkan pada tabel 4.10 di atas maka dapat disimpulkan bahwa keterampilan belajar siswa melalui layanan bimbingan kelompok pada siklus II memperoleh nilai rata-rata sebesar 35 dan dikategorikan baik. Hal tersebut menunjukkan adanya peningkatan bila dibandingkan dengan siklus I yang hanya memperoleh nilai ratarata sebesar 23 dan dikategorikan kurang. Melihat perbandingan tersebut, pada siklus II ini memperoleh peningkatan rata-rata sebesar 12. Dengan demikian, penelitian tindakan bimbingan dan konseling (PTBK) sudah dianggap cukup sampai pada siklus II karena keterampilan belajar siswa sudah dalam kategori baik.

\section{7) Uji Hipotesis Tindakan}

Berdasarkan hasil penelitian yang telah dikemukakan di atas maka hipotesis yang menyatakan "terjadi peningkatan keterampilan belajar siswa melalui bimbingan kelompok” diterima karena teruji kebenarannya.

\section{Hasil Pembahasan}

\section{a. Hasil Pembahasan Siklus I}

Dalam pelaksanaan layanan bimbingan kelompok sebagai upaya meningkatkan keterampilan belajar siswa pada siklus I observasi terhadap aktivitas peneliti dalam kategori cukup. Pada pertemuan pertama kegiatan peneliti mendapatkan hasil 42 dengan kategori kurang. Hal ini disebabkan peneliti lebih mendominasi peran sebagai pemimpin kelompok, kurang memperhatikan keikutsertaan siswa, dan kurang dalam mengendalikan diri. Selanjutnya pada pertemuan kedua, aktivitas peneliti mendapatkan hasil 52 ada peningkatan 10 . Pada pertemuan kedua ini, peneliti lebih bisa menghidupkan suasana dalam kelompok melalui dinamika kelompok sehingga siswa merasa lebih aktif dalam layanan bimbingan kelompok. Layanan bimbingan kelompok merupakam proses pemberian informasi dan bantuan yang diberikan oleh seorang yang ahli (konselor) pada sekelompok orang dengan memanfaatkan dinamika kelompok guna mencapai suatu tujuan tertentu. Sesuai dengan pendapat Santoso (2004: 5) dinamika 
kelompok berarti suatu kelompok yang terbentuk dari dua individu atau lebih yang mempunyai hubungan psikologis secara jelas antara anggota yang satu dengan yang lain. Dengan kata lain, antar anggota kelompok mempunyai hubungan psikologis yang berlangsung dalam situasi yang dialami secara bersama-sama.

Sedangkan hasil observasi terhadap aktivitas siswa selama mengikuti layanan bimbingan kelompok pada siklus I pertemuan pertama, aktivitas siswa dalam mengikuti layanan bimbingan kelompok baru mencapai skor 21. Hal ini menunjukkan bahwa siswa belum begitu antusias dalam mengikuti layanan bimbingan kelompok. Pada pertemuan kedua, aktivitas siswa dalam mengikuti layanan bimbingan kelompok diperoleh hasil sebesar 29, ada peningkatan sebesar 7. Peningkatan ini terjadi karena siswa sudah dapat berperan sesuai dengan fungsinya yaitu dapat berpartisipasi aktif dalam layanan bimbingan kelompok. Penelitian ini sesuai dengan teori dari Wibowo (2005: 18) bahwa peranan anggota kelompok dalam bimbingan kelompok, yaitu aktif membahas permasalahan atau topik umum tertentu yang hasil pembahsannya berguna bagi para anggota kelompok.

\section{b. Hasil Pembahasan Siklus II}

Peneliti melakukan perbaikan pada kelemahan-kelemahan yang ditemukan pada siklus I. Peneliti melakukan berbagai inovasi agar siswa dapat berpartisipasi aktif dalam layanan bimbingan kelompok. Peneliti memberikan informasi yang berkaitan dengan masalah siswa dengan memanfaatkan dinamika kelompok untuk mencapai tujuan, yaitu meningkatkan keterampilan belajar siswa. Dari hasil pengamatan terhadap aktivitas siswa dalam mengikuti layanan bimbingan kelompok, tampak anggota kelompok sangat antusias dan berpartisipasi aktif untuk mencapai tujuan bersama. Sesuai dengan penjelasan Wibowo (2005: 18) bahwa peranan anggota kelompok dalam layanan bimbingan kelompok meliputi (1) berpartisipasi aktif dalam dinamika interaksi sosial, (2) menyumbang bagi pembahasan masalah, dan (3) menyerap berbagai informasi untuk diri sendiri. Dalam aktivitas layanan ini terbentuk suasana interaksi multiarah dan mendalam dengan melibatkan aspek kognitif. Sedangkan hasil pengamatan terhadap keterampilan belajar siswa dapat dikatakan 
meningkat dengan kategori baik. Siswa memiliki keterampilan belajar seperti dapat membuat jadwal harian, memiliki kemauan belajar yang kuat, memperhatikan pada saat pelajaran, berani bertanya kepada guru, berani menjawab pertanyaan yang diberikan oleh guru, mencatat materi pelajaran, membuat ringkasan, menggunakan buku dan internet sebgai sumber belajar, dan mau memepersiapkan diri menghadapi ujian, serta mempersiapkan strategi menerjakan soal ujian.

\section{Simpulan}

Simpulan penelitian ini adalah aktivitas peneliti mengalami peningkatan dalam memberikan layanan bimbingan kelompok kepada siswa mulai dari siklus I hingga siklus II. Peningkatan ini sebagai wujud penerapan layanan bimbingan kelompok untuk meningkatkan keterampilan belajar siswa. Peningkatan aktivitas peneliti berkat masukan dan saran dari kolaborator terhadap peneliti saat melaksanakan layanan bimbingan kelompok. Keterampilan belajar siswa mengalami peningkatan dari siklus I memperoleh rata-rata sebesar 23 dengan kategori kurang, sedangkan pada siklus II memperoleh rat-rata sebesar 35 dengan kategori baik. Maka perbandingan antara siklus I dengan siklus II mengalami peningkatan sebesar 12, artinya, siswa mengalami peningkatan dalam keterampilan belajarnya yaitu siswa memiliki keterampilan belajar seperti dapat membuat jadwal harian, memiliki kemauan belajar yang kuat, memperhatikan pada saat pelajaran, berani bertanya kepada guru, berani menjawab pertanyaan yang diberikan oleh guru, mencatat materi pelajaran, membuat ringkasan, menggunakan buku dan internet sebgai sumber belajar, dan mau memepersiapkan diri meghadapi ujian, serta mempersiapkan strategi menerjakan soal ujian. Berdasarkan hasil penelitian di atas maka saran dalam penelitian ini adalah bagi guru pembimbing dalam menyelenggarakan layanan bimbingan kelompok secara efektif untuk meningkatkan keterampilan belajar siswa. Sedangkan bagi sekolah agar dapat meningkatkan fasilitas baik berupa sarana dan prasarana yang mendukung pelaksanaan layanan bimbingan dan konseling, khususnya ruangan bimbingan yang lebih nyaman. 


\section{DAFTAR PUSTAKA}

Gibson, Robert L. dan Mitchell, Marianne H. 2011. Bimbingan dan Konseling. Yogyakarta: Pustaka Pelajar.

Glading, Samuel T. 2012. Konseling Profesi Yang Menyeluruh. Jakarta: Indeks.

Handarini, Dany M. 2013. Materi Pelatihan 5 Tes Minat Jabatan. Malang: Pasca Sarjana Universitas Negeri Malang.

Latipun. 2010. Psikologi Konseling. Malang: UMM Press.

Prayitno. 2004. Layanan Bimbingan dan Konseling Kelompok (Dasar Dan Profil, Jakarta: Ghalia Indonesia.

Raharjo, Susilo dan Gudnanto. 2011. Pemahaman Individu Tehnik Non Tes, Kudus: Nora Pustaka Enterprise.

Slameto. 1995. Belajar dan Faktor-faktor yang Mempengaruhinya. Jakarta: Rineka Cipta.

Soemarjadi, Muzni Ramanto, dan Wikdati Zahri. 1991. Pendidikan Keterampilan. Jakarta: Depdikbud.

Sukardi, Dewa Ketut. 2008. Pengantar Pelaksanaan Program Bimbingan dan Konseling di Sekolah. Jakarta: Rineka Cipta.

Suryabrata, Sumadi. Psikologi Pendidikan. Jakarta: Raja Grafindo Persada.

Sutoyo, Anwar. 2009. Pemahaman Individu. Semarang: Widya Karya.

Syah, Muhibbin. 2004. Psikologi Belajar. Jakarta: Raja Grafindo Persada.

Tohirin. 2013. Bimbingan dan Konseling di Sekolah dan Madrasah (Berbasis Integrasi). Jakarta: Raja Grafindo Persada. 